\title{
STUDI PENGARUH pH AWAL MEDIA DAN LAMA FERMENTASI \\ PADA PROSES PRODUKSI ETANOL DARI HIDROLISAT TEPUNG BIJI NANGKA DENGAN MENGGUNAKAN Saccharomycess cerevisiae
}

\author{
Umi Fadilah ${ }^{1}$, I Made Mahaputra Wijaya ${ }^{2}$, N. Semadi Antara ${ }^{2}$ \\ ${ }^{1}$ Mahasiswa Jurusan Teknologi Industri Pertanian, Fakultas Teknologi Pertanian Unud \\ ${ }^{2}$ Dosen Teknologi Industri Pertanian, Fakultas Teknologi Pertanian Unud \\ Email: umifadilah04@gmail.com ${ }^{1}$ \\ Email koresponden: mahaputrawijaya@unud.ac.id ${ }^{2}$
}

\begin{abstract}
Jackfruit seed (Artocarpus heterophyllus) flour is a substrate used in ethanol production research. The purpose of this study was to determine the effect of the media initial $\mathrm{pH}$ and the time length of fermentation on the ethanol fermentation process from the jackfruit seed starch hydrolyzate using Saccharomyces cerevisiae and to obtain optimum initial $\mathrm{pH}$ of the medium and the optimum fermentation length in order to obtain the highest ethanol concentration. This research was designed with 2 factors. The first factor is the initial $\mathrm{pH}$ of the media consisting of 3 levels, namely 4, 4,5, and 5. The second factor is the fermentation length consisting of three levels, ie 5, 6, and 7 days. Data obtained from the research are analyzed and presented descriptively. The results showed that the initial $\mathrm{pH}$ of the media had an effect on ethanol content and final $\mathrm{pH}$, but had no effect on total soluble solids. Hydrolyzate of jackfruit flour, fermentation length has an effect on total ethanol, final $\mathrm{pH}$, and total dissolved solids. The interaction of the two treatments had an effect on total ethanol of fermented jackfruit seed flour. The best treatment to produce ethanol hydrolyzate of jackfruit seed flour is the initial $\mathrm{pH}$ of medium 4.5 and the duration of fermentation of 6 days to produce total ethanol of $3.67 \mathrm{~mL}$.
\end{abstract}

Key words: Artocarpus heterophyllus, ethanol, fermentation, initial pH of medium

\section{PENDAHULUAN}

Nangka banyak terdapat di Indonesia dan bijinya belum dimanfaatkan dengan optimal, dalam penelitian Anneahira (2010), biji nangka mengandung karbohidrat, protein, dan energi. Selain itu, biji nangka juga mengandung mineral seperti kalsium dan fosfor. Kandungan gizi yang terdapat dalam biji nangka per 100 gram yaitu mengandung energi sebesar $165 \mathrm{kkal}$, karbohidrat 36,7 g, protein 4,2 g, lemak 0,1 g, kalsium $33 \mathrm{mg}$, fosfor $200 \mathrm{mg}$, dan zat besi $1 \mathrm{mg}$ (Daryanto, 2006). Selain itu, di dalam biji nangka juga terkandung vitamin B 0,2 mg dan vitamin C $10 \mathrm{mg}$ (Daryanto, 2006). Adanya kandungan karbohidrat, dalam biji nangka memungkinkan dimanfaatkan untuk dijadikan tepung dan difermentasi menjadi etanol.

Pembuatan etanol dari bahan berkarbohidrat dalam hal ini memerlukan reaksi hidrolisis dan dilanjutkan dengan fermentasi alkohol yang mengubah glukosa menjadi etanol dengan menambah yeast atau ragi (Khamdiyah, 2010). Reaksi hidrolisis merupakan reaksi yang melibatkan air sebagai reaktan agar suatu persenyawaan dapat terpecah atau terurai (Dyah, 2009). Reaksi hidrolisis merupakan reaksi yang berlangsung lambat, karenanya untuk mempercepat laju sering ditambahkan katalis. Katalis yang 
dapat dipakai pada reaksi hidrolisis pati adalah katalis asam, seperti asam mineral $\mathrm{HCl}$ atau $\mathrm{H}_{2} \mathrm{SO}_{4}$ (Minarni, 2013). Metode hidrolisis asam masih lebih banyak diterapkan baik dalam penelitian maupun industri. Dengan demikian, maka dalam penelitian ini digunakan metode hidrolisis asam dengan $\mathrm{H}_{2} \mathrm{SO}_{4}$ karena mudah didapat dan harga relatif murah.

Fermentasi merupakan proses perubahan kimia yang disebabkan oleh aktivitas mikroorganisme untuk memperoleh energi dengan memecah substrat untuk pertumbuhan dan metabolisme dari mikroorganisme tersebut. Proses fermentasi yang terjadi pada pembentukan etanol adalah fermentasi anaerob, atau tanpa oksigen (Minarni, 2013). Penggunaan khamir S. cerevisiae banyak digunakan untuk meningkatkan hasil produksi etanol dari gula karena tidak membutuhkan sinar matahari dalam pertumbuhannya (Purwanto, 2012).

Atas dasar hal-hal tersebut, maka dilakukan penelitian mengenai studi pengaruh $\mathrm{pH}$ awal media dan lama fermentasi pada proses produksi etanol dari hidrolisat tepung biji nangka. Penelitian ini dilakukan dengan tujuan untuk mengetahui studi pengaruh $\mathrm{pH}$ awal media dan lama fermentasi terhadap proses produksi etanol dari hidrolisat tepung biji nangka dan untuk mengetahui perlakuan $\mathrm{pH}$ awal media dan lama fermentasi terbaik, dalam menghasilkan total etanol dari hidrolisat tepung biji nangka.

\section{METODE PENELITIAN}

\section{Tempat dan Waktu}

Penelitian ini dilakukan di Laboratorium Bioindustri dan Lingkungan, Mikrobiologi Pangan, dan Laboratorium Analisis Pangan, Fakultas Teknologi Pertanian Universitas Udayana. Penelitian ini dilakukan selama 4 bulan yaitu dari Agustus sampai dengan November 2017.

\section{Bahan dan Alat}

Bahan utama pada penelitian ini adalah biji nangka yang didapatkan dari Desa Bungaya Kangin, Kecamatan Bebandem, Karangasem, Bali. Khamir yang dipergunakan Saccharomycess cerevisiae JCM 7255 yang didapatkan dari Universitas Gadjah Mada. Bahan bahan untuk propagasi mikroorganisme meliputi yeast ekstrak, pepton, glukosa, dan bahan kimia yang dipergunakan adalah $\mathrm{NaOH}, \mathrm{HCL}, \mathrm{H}_{2} \mathrm{SO}_{4}$, indikator $\mathrm{PP}, \mathrm{NaCl}$ (Merck), alkohol 70\% (Brataco chemika).

Peralatan yang digunakan dalam penelitian ini antara lain : distilator 2 tingkat, wadah fermentasi berupa botol kaca kapasitas $1 \mathrm{~L}$, timbangan analitik (Shimadzu/ATY 224), water bath (Thermology), pH meter (Senz pH digital tester), labu ukur (Iwaki 
inkubator (Mommert), tabung reaksi (Iwaki Pirex), lampu bunsen, laminar flow (Wina/SL-170), shaker (Health/H-MSR), dan alat-alat gelas.

\section{Rancangan Percobaan}

Penelitian yang dilakukan merupakan penelitian eksperimen dalam skala laboratorium dengan perlakuan yang dirancang dengan dua faktor. Faktor pertama yaitu $\mathrm{pH}$ awal proses fermentasi (P) yang terdiri dari 3 taraf, yaitu : P1 (pH 4), P2 (pH 4,5) dan P3 ( pH 5). Faktor kedua yaitu lama fermentasi (T) yang terdiri dari 3 taraf yaitu : T1 (5 Hari), T2 (6 Hari) dan T3 (7 Hari). Dilakukan 3 kali ulangan, untuk masing-masing kombinasi perlakuan sehingga diperoleh 27 unit percobaan. Data yang diperoleh dari serangkaian pengujian kemudian dianalisis dan dipaparkan secara deskriptif dan ditampilkan dalam bentuk grafik, tabel, gambar, maupun foto.

\section{Pelaksanaan Penelitian}

\section{Pembuatan Tepung Biji Nangka}

Proses pembuatan tepung biji nangka melalui tahapan pencucian, perebusan, pengupasan, pengirisan, pengeringan pada suhu $50 \pm{ }^{\circ} \mathrm{C}$ selama $15 \mathrm{jam}$, penepungan, dan pengayakan menggunakan ayakan 80 mesh (Diah, 2011). Pengeringan biji nangka menggunakan oven pada suhu $50 \pm{ }^{\circ} \mathrm{C}$ selama 15 jam bertujuan untuk mendapat kadar air $10 \pm \%$ (Lubis, 2005).

\section{Proses Hidrolisis Tepung Biji Nangka}

Proses hidrolisis dilakukan secara kimiawi yaitu dengan menambahkan asam sulfat $\left(\mathrm{H}_{2} \mathrm{SO}_{4}\right) 5 \mathrm{~N}$ ke dalam campuran tepung biji nangka $100 \mathrm{~g}$ dan aquades $500 \mathrm{~mL}$ sampai mencapai $\mathrm{pH} 2,5$. Selanjutnya dilakukan pemanasan pada suhu $121{ }^{\circ} \mathrm{C}$ selama 30 menit didalam otoklaf (Rahayu et al., 2010).

\section{Pembuatan Inokulum Saccharomycess cerevisiae}

1. Peremajaan isolat Saccaharomycess cerevisiae JCM 7255

Kultur Saccharomycess cerevisiae disegarkan dengan cara diambil $1 \mathrm{~mL}$ kemudian diinokulasi ke dalam tabung reaksi yang telah diisi dengan media Pepton Glucose Yeast (PGY) steril sebanyak $10 \mathrm{~mL}$, kemudian diinkubasi pada suhu $28^{\circ} \mathrm{C}$ selama 24 jam.

2. Perbanyakan isolat Saccaharomycess cerevisiae JCM 7255

Media PGY dibuat dengan mencampurkan 0,5\% $(b / v=1 \mathrm{~g})$ yeast ekstrak, $0,5 \%(b / v=$ $1 \mathrm{~g})$ pepton, dan $1 \%(\mathrm{~b} / \mathrm{v}=2 \mathrm{~g})$ glukosa yang dilarutkan dalam $200 \mathrm{~mL}$ aquades. 
Selanjutnya media disterilisasi pada suhu $121{ }^{\circ} \mathrm{C}$ selama 15 menit di dalam otoklaf. Isolat hasil peremajaan divorteks, sebelum diperbanyak. Kemudian perbanyakan dilakukan dengan cara menuangkan $10 \%(b / v)$ isolat hasil peremajaan ke erlenmeyer yang berisi media PGY yang sudah disterilisasi. Setelah itu, hasil perbanyakan diinkubasi dengan suhu $28{ }^{\circ} \mathrm{C}$ selama 48 jam (Tang et al., 2013).

3. Pembuatan starter

Kultur hasil perbanyakan divorteks, selanjutnya dimasukkan ke dalam tabung-tabung falcon steril. Kultur dalam falcon lalu disentrifugasi dengan kecepatan $5000 \mathrm{rpm}$ pada suhu $4^{\circ} \mathrm{C}$ selama 20 menit. Cairan bagian atas yang disebut supernatan dibuang. Setelah itu ambil $0.1 \mathrm{~mL}$ kultur dan ditambahkan $9,9 \mathrm{~mL} \mathrm{NaCl}$ untuk dilakukan pengecekan OD 5 pada spektrofotometer dengan $\lambda 660 \mathrm{~nm}$.

\section{Proses Fermentasi Produksi Etanol}

Tahap fermentasi dilakukan dengan cara memasukkan tepung biji nangka hasil hidrolisis sebanyak 50 gram kedalam botol fermentasi $1000 \mathrm{~mL}$ media yang telah disterilisasi, kemudian pHnya diatur sesuai dengan perlakuan ( $\mathrm{pH} \mathrm{4,} \mathrm{4.5,} \mathrm{5).} \mathrm{Jika} \mathrm{pH}$ awal media dibawah $\mathrm{pH}$ hidrolisis ditambahkan $\mathrm{NaOH}$ sebaliknya jika $\mathrm{pH}$ awal media diatas pH hidrolisis ditambahkan $\mathrm{HCl}$ (Cece R, 2013). Selanjutnya diinokulasikan dengan inokulum Saccharomycess cerevisiae yang telah dibuat, ditambahkan sebanyak 1\% (10 $\mathrm{mL}$ ) dari volume total. Kemudian difermentasi selama 5, 6, dan 7 hari dengan suhu ruangan $29-31^{\circ} \mathrm{C}$. Proses fermentasi tepung biji nangka dapat dilihat pada Gambar 1.

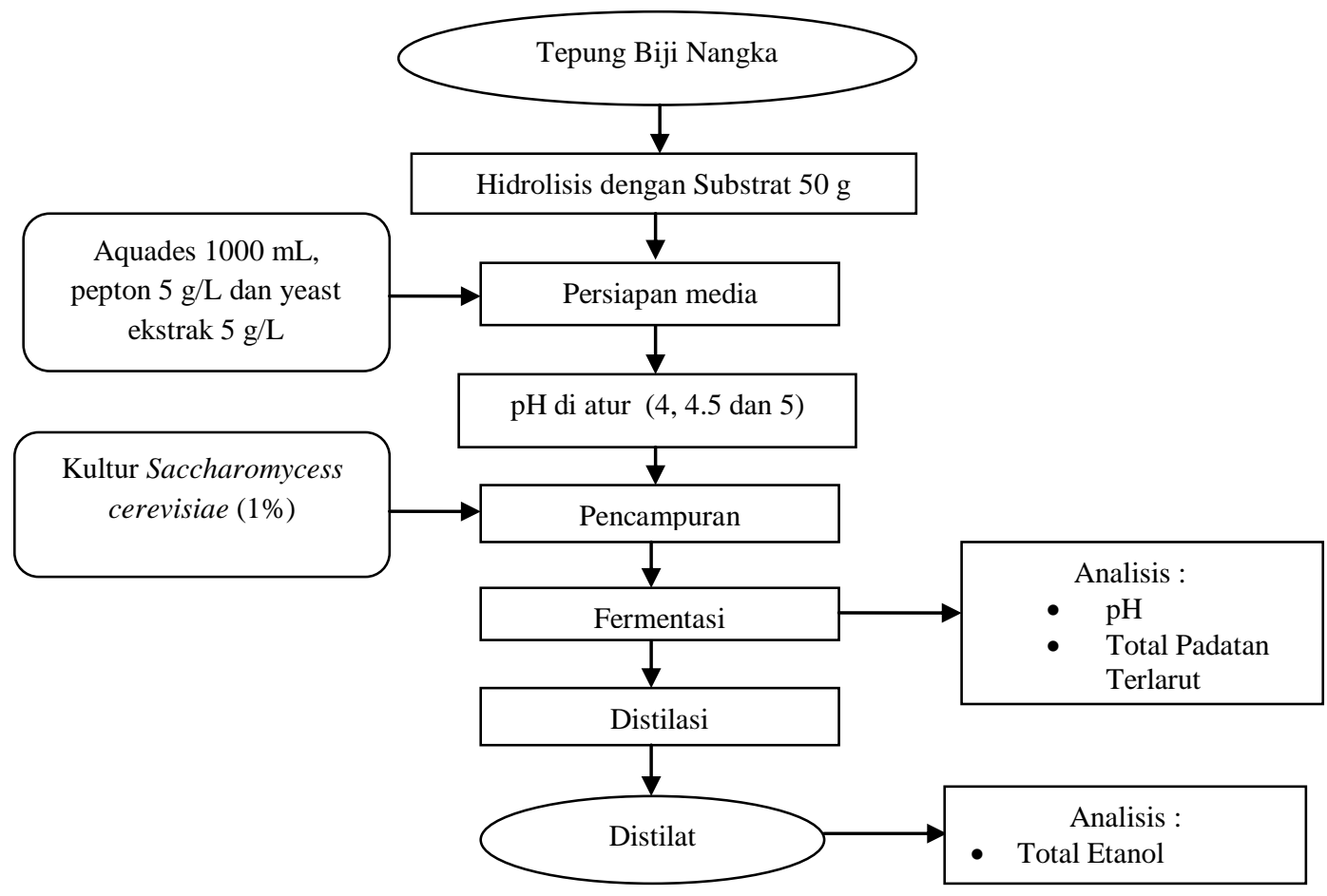

Gambar 1. Diagram Proses Fermentasi Tepung Biji Nangka 


\section{Variabel yang Diamati}

Variabel yang diamati pada fermentasi yaitu penentuan derajat keasaman (Sudarmadji et al., 1997), total padatan terlarut (Sudarmadji et al., 1997), dan total kadar etanol.

\section{HASIL DAN PEMBAHASAN}

\section{Derajat Keasaman ( pH )}

Derajat keasaman atau $\mathrm{pH}$ merupakan salah satu faktor penting yang mempengaruhi pertumbuhan mikroorganisme dan pembentukan produk dalam proses fermentasi karena setiap mikroorganisme mempunyai kisaran $\mathrm{pH}$ optimal terhadap lingkungan hidupnya. Hasil penelitian menunjukkan bahwa perlakuan $\mathrm{pH}$ awal media dan lama fermentasi memperlihatkan peningkatan nilai $\mathrm{pH}$ akhir fermentasi selama 5 hari dan lebih rendah selama fermentasi 6 hari dibandingkan $\mathrm{pH}$ awal. Nilai rata-rata $\mathrm{pH}$ akhir fermentasi tepung biji nangka dapat dilihat pada Gambar 2.

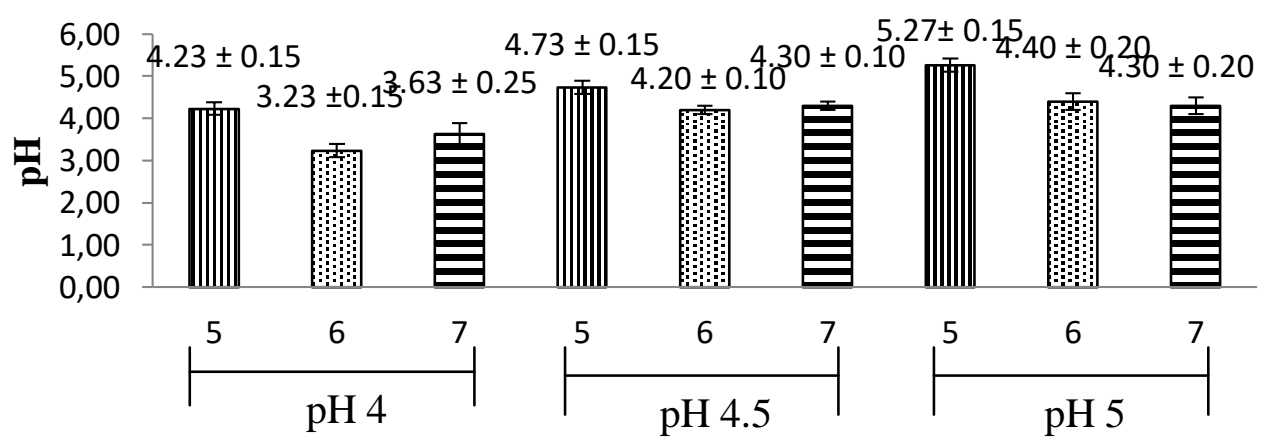

Lama Fermentasi (Hari)

Gambar 2. Nilai Derajat Keasaman (pH) Fermentasi Tepung Biji Nangka

Terjadinya peningkatan nilai $\mathrm{pH}$ media pada fermentasi 5 hari tepung biji nangka disebabkan karena yeast mengalami fase pertumbuhan, sehingga proses perombakan gula menjadi etanol cepat. Dampak yang ditimbulkan dari fase pertumbuhan yaitu dapat meningkatkan jumlah gugus $\mathrm{OH}^{-}$sehingga $\mathrm{pH}$ meningkat. Oleh karena adanya fase pertumbuhan dari yeast, maka terjadi peningkatan gugus $\mathrm{OH}^{-}$akibat dari penguraian gula menjadi etanol. Dengan demikian $\mathrm{pH}$ hasil fermentasi selama 5 hari meningkat dari pH awal media 4 menjadi 4.23, $\mathrm{pH}$ awal media 4.5 menjadi 4.73, dan $\mathrm{pH}$ awal media 5 
menjadi 5.27. Etanol mempunyai gugus $\mathrm{OH}$ yang bersifat basa maka gugus $\mathrm{OH}$ pada fermentasi 5 hari meningkat sehingga menaikkan $\mathrm{pH}$ sistem.

Sedangkan pada fermentasi selama 6 hari dan 7 hari $\mathrm{pH}$ akhir mengalami penurunan, dikarenakan selama proses fermentasi akan menghasilkan gas $\mathrm{CO}_{2}$ terlarut yang bersifat asam $\left(\mathrm{H}_{2} \mathrm{CO}_{3}\right)$. Penurunan $\mathrm{pH}$ juga diakibatkan karena fermentasi menghasilkan asam organik. Menurut Putra dan Amran (2009), penurunan keasaman juga disebabkan karena fermentasi akan menghasilkan asam organik oleh mikroba. Asamasam organik tersebut seperti asam malat, asam tartarat, asam sitrat, asam laktat, asam asetat, asam butirat dan asam propionat sebagai hasil sampingan, asam ini menurunkan pH medium. Dapat disimpulkan semakin lama fermentasi maka pH semakin kecil.

\section{Total Padatan Terlarut $\left({ }^{\circ}\right.$ Brix)}

Hasil penelitian menunjukkan bahwa perlakuan lama fermentasi memperlihatkan nilai total padatan terlarut menurun. Nilai rata-rata total padatan terlarut pada fermentasi tepung biji nangka dapat dilihat pada Gambar 3.

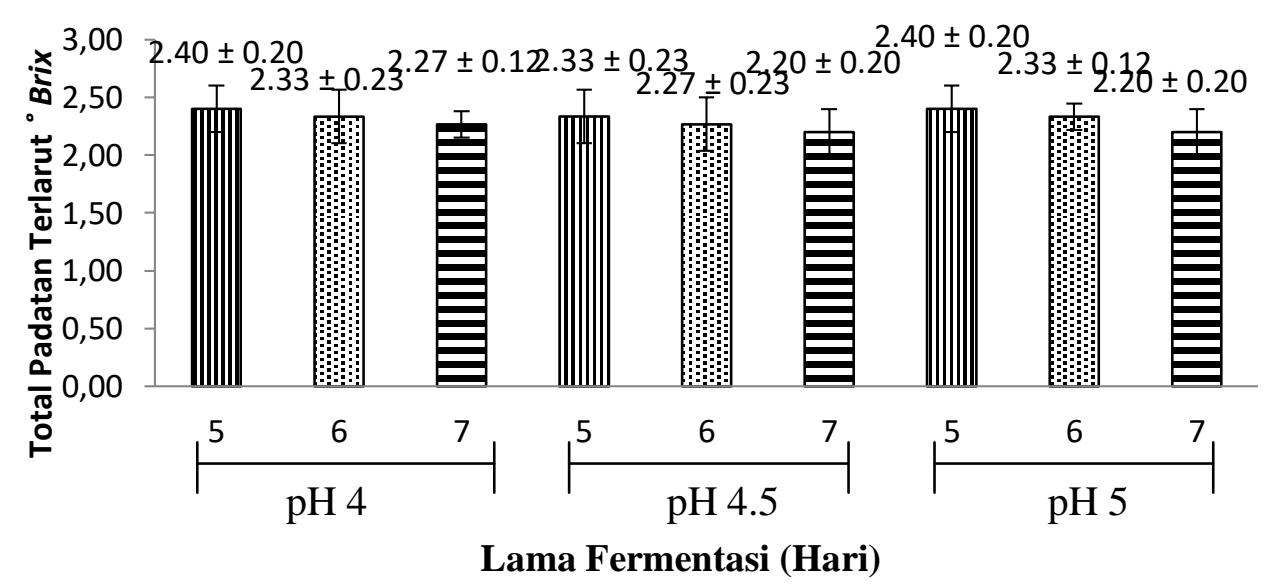

Gambar 3. Total Padatan Terlarut Fermentasi Tepung Biji Nangka

Berdasarkan gambar di atas, nilai total padatan terlarut pada perlakuan lama fermentasi mengalami penurunan seiring bertambahnya lama fermentasi. Total padatan terlarut merepresentasikan jumlah gula pereduksi yang terdapat pada bahan (Winarno et $a l, 1990)$. Perbedaan kadar total padatan terlarut ini diduga karena inokulum S. cerevisiae tidak dapat mengubah karbohidrat dan gula yang terkandung didalam tepung biji nangka untuk metabolisme dan produksi etanol sehingga mempengaruhi kualitas total padatan terlarut. Menurut Sintasari (2014) tingginya padatan terlarut disebabkan karena asamasam organik yang terlarut menjadi salah satu penyebab tingginya padatan terlarut. 
Rendahnya total padatan terlarut diduga karena selama proses fermentasi berlangsung, gula yang merupakan komponen padatan yang dominan dalam medium dimetabolisme oleh khamir menjadi alkohol dan $\mathrm{CO}_{2}$ sehingga total padatan terlarut menjadi rendah. Hal ini diperkuat dengan pernyataan Sartika (2010) penurunan total padatan terlarut selama penyimpanan disebabkan gula yang terkandung akan mengalami perubahan menjadi alkohol. Sisa-sisa asam organik, sukrosa maupun laktosa yang terlarut dalam air inilah yang akan terhitung sebagai total padatan terlarut (Sintasari, 2014).

Total padatan terlarut pada fermentasi hidrolisat tepung biji nangka dipengaruhi oleh lama fermentasi. Semakin lama proses fermentasi berlangsung total padatan terlarut pada fermentasi hidrolisat tepung biji nangka menurun, dari total padatan awal fermentasi selama 5 hari pH 4 sebesar $6{ }^{\circ}$ Brix menjadi 2,4 ${ }^{\circ}$ Brix. Hal ini diduga disebabkan oleh berkurangnya gula yang terlarut dalam cairan. Berkurangnya gula disebabkan oleh khamir yang menggunakan gula sebagai sumber karbon untuk melakukan metabolisme (Sintasari, 2014).

Gambar 3 menunjukkan bahwa total padatan terlarut terendah terdapat pada perlakuan lama fermentasi selama 7 hari sebesar $2,2{ }^{\circ}$ Brix, dan tertinggi terdapat pada lama fementasi selama 5 hari sebesar $2,4^{\circ}$ Brix. Hasil ini menunjukkan bahwa selama 7 hari fermentasi, total padatan terlarut cenderung menurun. Penurunan nilai total padatan terlarut sejalan dengan lamanya waktu fermentasi. Penurunan total padatan terlarut dimungkinkan karena terjadi proses pemecahan gula menjadi alkohol sehingga kandungan gula mengalami penurunan yang mengakibatkan nilai total padatan terlarut juga menurun (Reed dan Nagodawithana, 1991).

\section{Total Etanol (mL)}

Nilai total etanol tertinggi pada fermentasi hidrolisat tepung biji nangka dapat dilihat pada Gambar 4.

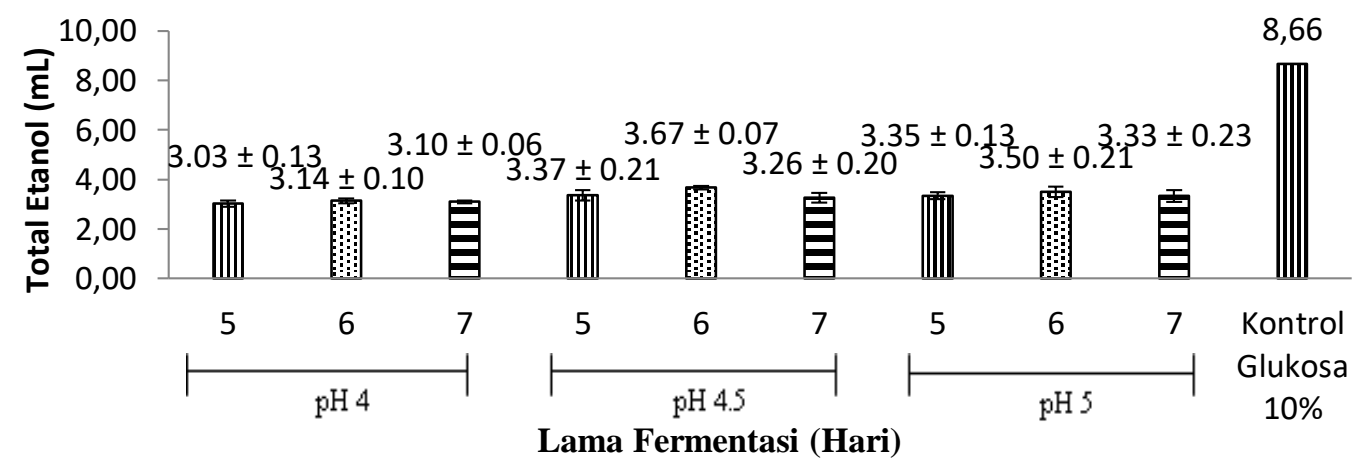

Gambar 4. Total Etanol (mL) Fermentasi Tepung Biji Nangka 
Hasil penelitian menunjukkan bahwa total etanol tertinggi terdapat pada lama fermentasi selama 6 hari dengan $\mathrm{pH}$ awal media 4.5 sebesar 3,67 mL. Hal ini karena pada waktu tersebut, pertumbuhan ragi berada pada fase eksponensial yaitu fase perkembangan ragi yang meningkat sehingga ragi bekerja secara optimum untuk mengubah glukosa menjadi etanol. Hal ini diperkuat dengan penelitian Hartono dan Halifah (2011) yang menyatakan bahwa lama fermentasi 144 jam ( 6 hari ) terjadi peningkatan, pada waktu ini pertumbuhan memasuki fase eksponensial, sehingga jumlah mikroorganisme yang dihasilkan meningkat dan aktivitas amilase yang dihasilkan meningkat sehingga kadar etanol yang dihasilkan juga meningkat. Selanjutnya, terjadi penurunan total etanol pada waktu fermentasi selama 7 hari yang disebabkan jumlah mikroba semakin menurun dan nutrien yang ada semakin berkurang, selain itu bioetanol yang dihasilkan telah teroksidasi lebih lanjut menjadi asam karboksilat (Noviani et al., 2014).

Faktor penting lainnya yang mempengaruhi pertumbuhan Saccharomyces cerevisiae yaitu derajat keasaman $(\mathrm{pH})$. Oleh karena itu, pada awal pelaksanaan penelitian substrat diatur $\mathrm{pH}$ nya terlebih dahulu, masing-masing sebesar 4, 4.5 dan 5 . Pada $\mathrm{pH} 4$ fermentasi selama 6 hari menghasilkan total etanol sebesar 3,14 mL karena pertumbuhan dan aktivitas khamir belum maksimal.

S. cereviseae memasuki fase stasioner atau sudah tidak berkerja lagi secara optimal pada pH 5 diperoleh total etanol 3,50 mL dibandingkan dengan 3,67 $\mathrm{mL}$ pada $\mathrm{pH}$ 4,5. Fase ini disebabkan oleh kadar glukosa cenderung menurun, glukosa digunakan sebagai sumber karbon bagi sel khamir, sehingga khamir tidak dapat menguraikan glukosa untuk menjadi etanol dan sebagian khamir akan mati. Fase ini juga khamir menghasilkan produk samping, berupa asam asetat yang mengalami reaksi lanjut serta larutan pati menjadi 3 (tiga) lapisan yaitu lapisan bawah berupa endapan protein, air dan etanol (Volk, 1993).

Pada kenyataaannya koefisien konversi Saccharomycess cerevisiae JCM 7255 yaitu 5,6 \%. Sementara sekitar 94,4\% dipakai untuk metabolisme Saccharomycess cerevisiae atau tidak dikonversi menjadi alkohol, hal ini mungkin disebabkan karena kekurangan unsur mikro atau glukosa terlalu banyak.

Perbedaan antara kontrol penelitian dengan kontrol teoritis ini diduga disebabkan oleh beberapa faktor antara lain pengendalian suhu pada saat fermentasi. Pada saat dilakukan fermentasi, tidak dilakukan pengendalian terhadap suhu. Suhu yang digunakan dalam proses fermentasi seharusnya adalah antara $26-30{ }^{\circ} \mathrm{C}$ (Dwidjoseputro, 1990). Botol-botol fermentator seharusnya diletakkan di dalam kotak yang memiliki suhu pada rentang nilai di atas. Dalam penelitian ini, botol fermentator hanya diletakkan di dalam 
ruangan yang suhunya dapat dipengaruhi oleh suhu luar. Selain itu suhu pada proses distilasi juga mempengaruhi hasil etanol. Suhu yang paling efektif digunakan untuk proses distilasi bioetanol dari tepung biji nangka berkisar antara $70-90{ }^{\circ} \mathrm{C}$ (Nugroho, 2012). Titik didih etanol murni adalah $78{ }^{\circ} \mathrm{C}$, sementara titik didih air adalah $100{ }^{\circ} \mathrm{C}$ (kondisi standar). Pada saat dilakukan proses destilasi, suhu pada kompor listrik tingkat pertama tidak dapat diatur secara presisi.

Sedangkan perbedaan antara kontrol penelitian yang menghasilkan 8,66 mL etanol dengan sampel yang paling tinggi menghasilkan etanol pada $\mathrm{pH} 4,5$ fermentasi selama 6 hari yaitu 3,67 mL. Substrat 50 g menghasilkan total gula sebesar 8,14\% . Dengan demikian perbedaan antara kontrol penelitian 0,866 mL / \% gula dan sampel 0,46 $\mathrm{mL} / \%$ gula diduga disebabkan pada tepung biji nangka tidak hanya menghasilkan glukosa melainkan terkandung gula-gula lain seperti galaktosa, laktosa, dan sukrosa. Gula-gula tersebut kemudian akan dikonversi menjadi bioetanol dengan bantuan Saccharomyces cerevisiae. Saccharomyces cerevisiae dapat mengkonversi gula menjadi etanol karena adanya enzim invertase dan zimase. Dengan adanya enzim-enzim ini Saccharomyces cerevisiae memiliki kemampuan untuk mengkonversi baik gula dari kelompok monosakarida maupun dari kelompok disakarida. Jika gula yang tersedia dalam substrat merupakan gula disakarida maka enzim invertase akan bekerja menghidrolisis disakarida menjadi monosakarida. Setelah itu, enzim zymase akan mengubah monosakarida tersebut menjadi alkohol dan $\mathrm{CO}_{2}$. Hal ini sesuai dengan pernyataan Judoamidjojo et al., (1992), yang menyatakaan bahwa Saccharomyces cerevisiae dapat menghasilkan etanol yang berasal dari fermentasi gula. Gula akan diubah menjadi bentuk yang paling sederhana oleh enzim invertase kemudian gula sederhana tersebut akan dikonversi menjadi etanol dengan adanya enzim zymase. Kedua enzim tersebut dihasilkan oleh Saccharomyces cerevisiae. Meskipun Saccharomyces cerevisiae dapat mengubah gula sederhana menjadi etanol (Judoamidjojo et al., 1992).

\section{KESIMPULAN DAN SARAN}

\section{Kesimpulan}

Perlakuan terbaik untuk menghasilkan etanol hidrolisat tepung biji nangka adalah pH awal media 4,5 dan lama fermentasi 6 hari dengan menghasilkan total etanol sebesar $3,67 \mathrm{~mL}$. 
Saran

Penelitian lebih lanjut mengenai proses fermentasi etanol dari hidrolisat tepung biji nangka perlu dilakukan. Salah satunya dengan memvariasikan konsentrasi substrat. Hidrolisat yang digunakan hidrolisat murni yang tidak diencerkan.

\section{DAFTAR PUSTAKA}

Daryanto. 2006. Bercocok Tanam Buah-buahan. http://datasmaku.blogspot.co.id/2012/10/karya-ilmiah-membandingkanserbukbiji.html. Diakses pada tanggal 26 Maret 2017.

Diah, A. 2011. Pemanfaatan Biji Nangka pada Pembuatan Bakso. Universitas Negeri Surabaya, Surabaya.

Dyah, S. P. 2009. Pembuatan Glukosa Cair Dari Bahan Baku Rebung (Production Of Liquid Glucose from Bamboo Shoots). Jurnal Kimia dan Teknologi. UPN "Veteran" Jawa Timur. ISSN 0216-163 X.

Elevri, P. A., dan S. R. Putra. 2006. Produksi Etanol Menggunakan Saccharomyces cerevisiae yang Diamobilisasi dengan Agar Batang. Kimia ITS. Akta Kamindo 1(2): 109-110.

Endah R., P. Sunarto dan R.F. Berta. 2009. Kinetika Reaksi Hidrolisis Tepung Sorgum Dengan Katalis Asam Klorida ( $\mathrm{HCl})$. Jurnal Ekuilibrium Teknik Kimia UNS 7(2):71-71

Endah, R.D., K.A. Enny, dan N. Adrian. 2009.Bioetanol Fuel Grade dari Talas (Colocasia Esculenta). Ekuilibrium, 8(1):1-6.

Fardiaz, S. 1992. Mikrobiologi Pangan. PT Gramedia Pustaka Utama, Jakarta.

Handayani, S.U. 2008. Pemanfaatan Bioethanol Sebagai Bahan Bakar Pengganti Bensin. Jurnal Teknik UNDIP : 99-102.

Judoamidjojo, M., A. A. Darwis, dan E. G. Sa'id. 1992. Teknologi Fermentasi. Edisi 1. Rajawali Press, Jakarta.

Noviani, H., Supartono dan K. Siadi. 2014. Pengolahan Limbah Serbuk Gergaji Kayu Sengon Laut menjadi Bioetanol menggunakan Saccharomyces cerevisiae. Indonesian Journal of Chemical Science 3(2):147-151.

O'Leary V. S., R. Green, B. C. Sullivan, and V. H. Holsinger. 2004. Alcohol production by selected yeast strains in lactase-hydrolyzed acid whey. Biotechnol Bioeng 19 (10): 19-35.

Putra., E. Agustinus dan Amran . 2009. Pembuatan Bioetanol Dari Nira Siwalan Secara Fermentasi Fase Cair Menggunakan Fermipan. Jurusan Teknik Kimia Universitas Diponegoro, Semarang.

Reed, G and T. W. Nagodawithana. 1991. Yeast Technology. Van Nostrand Reinhold Publisher, New York. 
Rubio dan M. A. Texeira. 2005. Comparative analiysis of the gal genetic switch between Not-So-Distant Cousins: Saccharomyces cerevisiae versus Kluyveromyces lactis. FEMS Yeast Res. 5: 1115-1128.

Sartika, R. (2010). Pengaruh Suhu dan Kelembaban Udara Terhadap Shelf-Life Dan Karakteristik Buah Manggis (Garcinia mangostana L.) Selama Pemyimpanan. Bogor: Fakultas Pertanian. IPB. 